\title{
Review of Nurses' Knowledge of Delirium, Dementia and Depressions (3Ds): Systematic Literature Review
}

\author{
Sara Mahmoud Yaghmour ${ }^{1}$, Leila Gholizadeh ${ }^{2}$ \\ ${ }^{1}$ Public Health Department, Faculty of Nursing, King Abdulaziz University, Jeddah, Saudi Arabia \\ ${ }^{2}$ Faculty of Health, University of Technology Sydney, Sydney, Australia \\ Email: smyaghmour1@kau.edu.sa, leila.gholizadeh@uts.edu.au
}

Received 16 January 2016; accepted 13 March 2016; published 16 March 2016

Copyright (C) 2016 by authors and Scientific Research Publishing Inc.

This work is licensed under the Creative Commons Attribution International License (CC BY).

http://creativecommons.org/licenses/by/4.0/

(c) (i) Open Access

\begin{abstract}
This paper aims at reviewing literature on nurses' knowledge of delirium, dementia and depression (3Ds) which are rapidly increasing worldwide as the population ages, and to identify interventions that have shown effectiveness in improving nurses' knowledge level of these diseases. Nurses' knowledge of delirium, dementia and depression is essential to providing quality patient care. To access the literature, online databases including Medline (OVID), CINAHL (EBSCO), Nursing and Allied Health Source (ProQuest), and Health and Medicine (ProQuest), in addition to Google scholar search engine, were searched using key words "delirium", "dementia", "depression", "nurse", "knowledge" and their alternative words. Overall, 20 articles were found to meet the criteria for inclusion in the review. The study found that nurses' knowledge of the 3Ds was generally low, and they were not particularly able to differentiate between the three diseases. It is important that health care systems are adequately resourced to meet this growing challenge. Nurses should receive appropriate training about the 3Ds, and their knowledge be reinforced through continuing education.
\end{abstract}

\section{Keywords}

Nurses, 3Ds Knowledge, Health Education, Dementia, Delirium, Depression, Psychogeriatric

\section{Introduction}

The world's population is facing the problem of aging and onset age-associated diseases including mental and

How to cite this paper: Yaghmour, S.M. and Gholizadeh, L. (2016) Review of Nurses' Knowledge of Delirium, Dementia and Depressions (3Ds): Systematic Literature Review. Open Journal of Nursing, 6, 193-203.

http://dx.doi.org/10.4236/ojn.2016.63020 
cognitive disorders [1]. According to the World Health Organization (WHO), 15\% of the elderly population, aged 60 years and above, suffer from mental disorders [1], and there is a projection that by 2030 the number of elderly patients with mental disorders will equal or exceed that of younger age groups [2]. Accordingly, the management of mental disorders in the elderly population has become a major concern for healthcare providers and policy makers [3]. Elderly clients are often marginalized and their health needs are neglected, a situation that is more likely to be aggravated by addition of a mental illness [3]. The growing number of geriatric patients with mental health problems has, therefore, captured the attention of clinicians and researchers, and led to re-prioritization of healthcare resources to ensure efficient and effective outcomes for elderly patients with cognitive and mental conditions [3].

The prevalence of delirium among hospital patients ranges from $4 \%$ to $53 \%$, and it is considered the most prevalent acute psychogeriatric illness. Delirium is referred to as an altered state of consciousness that is accompanied by variations in cognition within few hours or days, reduced clarity of awareness of the environment and the ability to focus, shift, or sustain attention [4]. The delirium-associated changes in cognition are characterized by memory impairment, disorientation, and perceptual or linguistic deficit. There is also a possibility of disturbance in the sleep-wake cycle, emotional status, and hyperactivity or hypo-activity [5]. Delirium is more likely to be comorbid with dementia [6]. However, dementia remains the most prevalent chronic psychogeriatric condition among the elderly [7], with about $90 \%$ of nursing home residents suffering from this chronic disease [9]. Dementia is defined as a progressive neurodegenerative syndrome; with the commonly associated risk factors including Alzheimer's disease, vascular dementia, and rarer syndromes such as frontotemporal lobar degeneration [9]. Apart from delirium and dementia, depression is also prevalent among elderly people. The prevalence of depression among nursing home residents has been reported between $6 \%$ and $24 \%$. Depression is more prevalent in patients with dementia; with $14 \%$ to $39 \%$ of patients with dementia suffer from depression [10] [11].

Evidence from previous studies clearly indicates that geriatric patients with co-occurring mental illnesses present significant challenges to care providers [6] [12]-[14]. Generally, elderly patients have unique health care needs and they are more likely to suffer from multiple complications such as pressure ulcers, falls, functional incontinence, dehydration, and nutritional deficit [15]. These physical complications, coupled with cognitive and mental problems, present significant challenge to elderly care [16]. Given the fact of progressively aging population, healthcare demand for elderly patients presented with the 3Ds is also expected to grow. It is, therefore, important that healthcare providers, including nurses, become equipped with adequate knowledge and competencies to appropriately meet the increasing needs of the aging population. Accordingly, this study aims to review nurses' knowledge of the 3Ds, and identify effective educational practices, to help leverage nurses' knowledge of these diseases [3]. Knowledge-based effective professional practices are more likely to improve care for patients inflicted with such diseases.

\section{Methodology}

For this research study previously selected search keywords and phrases was utilised in combination with Boolean operators OR, as well as, AND. The previously selected keywords include "nurse", AND "knowledge" or "information" or "awareness" or "education" or "understanding". These keywords were combined separately with "depression", "delirium" and "dementia”. The search strategy has been designed on the basis of the Boolean search method and was run on relevant electronic databases, including MEDLINE (OVID), CINAHL (EBSCO), Nursing and Allied Health Source (ProQuest), and Health and Medicine (ProQuest) were searched for studies that addressed nurses' knowledge of the 3Ds and interventional studies that aimed at testing the effectiveness of educational programmes to enhance such knowledge. A further search, for the relevant literature, was carried out using Google Scholar. Articles published in peer-reviewed journals, in English, and during the last 10 years, were included. Studies that targeted patients, families, and health care providers other than nurses were excluded from this review. The database searches resulted in 248 articles after removing duplicates. The titles, abstracts, and full texts of these articles were reviewed for relevance, and finally, 20 articles were found to meet the eligibility criteria for this review. Among the 20 articles eight articles focused on knowledge assessment while the remaining 12 articles had looked at the effectiveness of interventions in improving nurses' knowledge. Moreover, among the articles, 11 were on delirium, 4 were on dementia and 5 were on depression. The following Figure 1 demonstrates the process of identifying the relevant articles. 


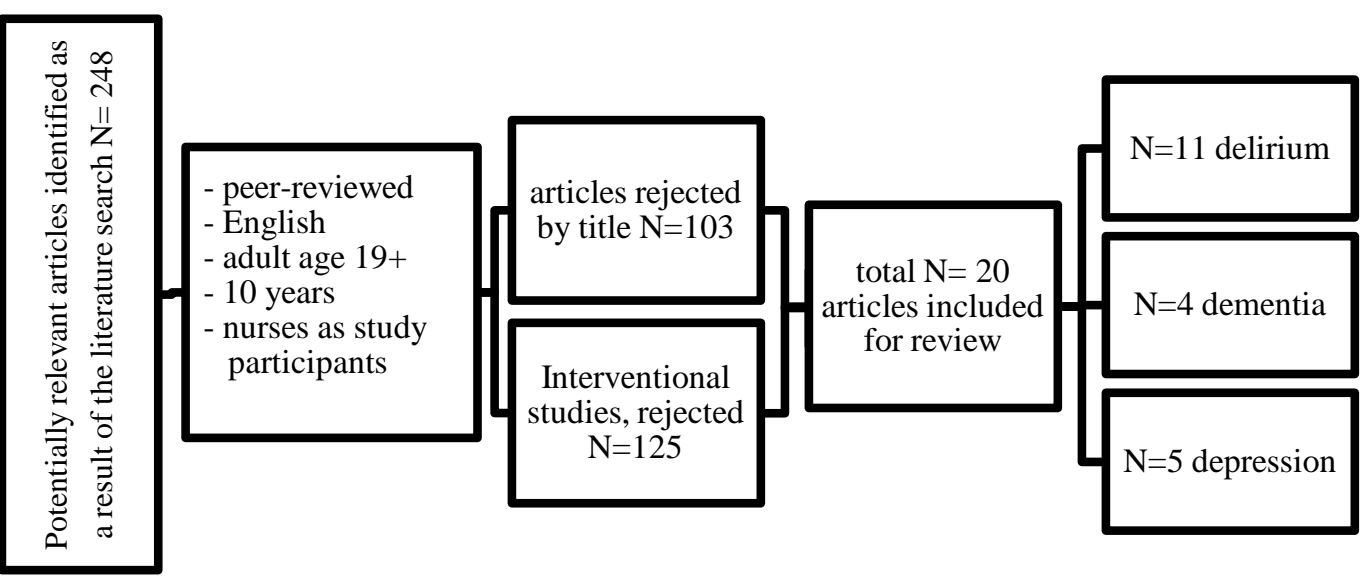

Figure 1. Study’s flowchart.

\section{Result}

Findings of this review on knowledge of nurses of delirium, dementia and depression and the effective educational interventions are presented separately below.

\subsection{Nurses Knowledge of Delirium and the Relevant Knowledge Development Interventions (Table 1)}

As identified in the methodology, 11 articles on delirium were reviewed. Among the 11 articles, seven were on knowledge of delirium and the remaining four articles were on knowledge development interventions. The studies by Baker at al. (2015), Christensen (2014), Flagg at al. (2010) and Hamdan-Mansour et al. (2010) used validated survey questionnaire as the assessment tools [17]-[20]. The study by Fick et al. (2007), on the other hand, used 5 validated case vignettes and the Mary Starke Harper Aging Knowledge Exam (MSHAKE), which are already validated [21]. The studies by Agar et al. (2011) used validated interview questions as the assessment tool and validated semi-structured interview questions and the study by Hosie et al. (2014) used a validated case vignette as the assessment tool [5] [22]. Interestingly, three of the studies were undertaken in USA, two were undertaken in Australia, one was undertaken in south-east Asia and one was undertaken in Jordan. The studies used various research designs/methods with five of the 7 studies being quantitative, one being qualitative and one being both qualitative and quantitative.

A study undertaken using non-experimental descriptive study on a sample of 60 nurses from acute care setting to explore nurses' knowledge regarding delirium and their opinion on their knowledge level found that only $64 \%$ of the nurses had adequate knowledge on delirium and this was dependent on education level, years of experience and area of practice [17]. Similarly, a study undertaken using a cross-sectional survey and two administered measures on a sample of 29 registered nurses from two medical units of an Academic Medical Centre to investigate nurses' knowledge of delirium superimposed on dementia found that the nurses had a high level of general geriatric nursing knowledge, but low knowledge on hypoactive delirium [21]. Interestingly, a study undertaken on a convenience sample of 61 registered nurses that included 31 medical-surgical nurses and 30 intensive care nurses using a descriptive cross-sectional study to assess the power of registered nurses to recognize delirium on medical-surgical and intensive care units differed slightly with the above findings by indicating that at least $90 \%$ of the nurses can identify hyperactive symptoms of delirium and at least $77 \%$ can identify the hypoactive symptoms of delirium [19]. To evaluate medical intensive care unit nurses' knowledge in identifying and managing delirium using a descriptive self-administered survey undertaken on a sample of 53 registered nurses from 13-bedded intensive care unit interestingly agreed with the above studies by indicating that the knowledge level was about 67.3\% [18]. Remarkably, the same study indicated that knowledge level for the signs and symptoms was 63.5\%, knowledge level for risk factors was 63.5\% and knowledge level for negative outcomes was 75\% [18]. Interestingly, a study undertaken to explore nurses’ knowledge and management skills of delirium in critical care units using a descriptive correlational study undertaken on a sample of 232 registered nurses in a critical care unit with a minimum of 6-months experience found that nurses' knowledge about deli- 
Table 1. Nurses knowledge of delirium and the relevant knowledge development interventions.

\begin{tabular}{|c|c|c|c|}
\hline Authors \& Year & Aim & Findings & Strength/Weakness \\
\hline $\begin{array}{l}\text { Agar et al. 2011, } \\
\text { Australia [5] }\end{array}$ & $\begin{array}{l}\text { Nurses' } \\
\text { understandings } \\
\text { of delirium } \\
\text { assessment } \\
\text { and management }\end{array}$ & $\begin{array}{l}\text {-No participant recognized the } \\
\text { diagnostic criteria of delirium } \\
\text {-Many recognized the cognitive } \\
\text { or behavioral manifestations } \\
\text {-The differences in recalling delirium etiology } \\
\text { depend on the participants' area of practice } \\
\text {-Whereas the limited understanding of } \\
\text { delirium and its management, the level } \\
\text { of confidence considered to be very high } \\
\text {-Participants were distressed while } \\
\text { trying to provide quality care }\end{array}$ & $\begin{array}{l}\text { Strength } \\
\text { Used a qualitative design } \\
\text { Audio-taping enhanced } \\
\text { message accurate capture } \\
\text { Weakness } \\
\text { The interview is subject to bias }\end{array}$ \\
\hline $\begin{array}{l}\text { Baker et al. } \\
\text { 2015, } \\
\text { USA [17] }\end{array}$ & $\begin{array}{l}\text { To explore nurses' } \\
\text { knowledge regarding } \\
\text { delirium and their } \\
\text { opinion on their } \\
\text { knowledge level }\end{array}$ & $\begin{array}{l}\text {-An average of correct answer } 64 \% \\
\text {-Only } 20 \% \text { had score } 75 \% \text { or greater } \\
\text {-There is a correlation between education } \\
\text { level, year of experience, or area of } \\
\text { practice with delirium general knowledge } \\
\text { and its risk factors in nurses }\end{array}$ & $\begin{array}{c}\text { Strength } \\
\text { Knowledge test allowed easy analysis } \\
\text { and quantification of Knowledge } \\
\text { Weakness } \\
\text { Results of Non-experimental design could } \\
\text { be less accurate than experimental ones }\end{array}$ \\
\hline $\begin{array}{l}\text { Christensen } \\
\text { 2014, South } \\
\text { East Asia } \\
\text { [18] }\end{array}$ & $\begin{array}{l}\text { Evaluate medical } \\
\text { intensive care unit } \\
\text { nurses' knowledge } \\
\text { in identifying and } \\
\text { managing delirium, } \\
\text { and study the impact } \\
\text { of their demographics } \\
\text { on knowledge of the } \\
\text { signs and symptoms, } \\
\text { risk factors and } \\
\text { negative outcomes }\end{array}$ & $\begin{array}{l}\text {-The overall positively answered } \\
\text { mean score was } 67.3 \% \\
\text {-Mean scores for knowledge of signs and } \\
\text { symptoms } 63.5 \% \text {, risk factors, } 63.5 \% \text { and } \\
\text { negative outcomes } 75 \%\end{array}$ & $\begin{array}{c}\text { Strengths } \\
\text { Use of likert scale enhanced } \\
\text { results analysis } \\
\text { Weaknesses } \\
\text { The study was open for } \\
\text { interviewer and respondent bias }\end{array}$ \\
\hline $\begin{array}{l}\text { Flagg et al. } \\
\text { 2010, Midwest, } \\
\text { USA [19] }\end{array}$ & $\begin{array}{l}\text { Assess the power of } \\
\text { registered nurses to } \\
\text { recognize delirium on } \\
\text { medical-surgical and } \\
\text { intensive care units }\end{array}$ & $\begin{array}{l}\text {-90\% identified the hyperactive } \\
\text { symptoms of delirium } \\
\text {-77\% were able to identify the } \\
\text { hypoactive symptoms } \\
\text {-Lack of awareness that delirium } \\
\text { assessment is necessary }\end{array}$ & $\begin{array}{c}\text { Strengths } \\
\text { Included participants from } \\
\text { different wards enhancing the } \\
\text { representation of participants } \\
\text { Weakness } \\
\text { Use of a convenient sample } \\
\text { limits generalization of results }\end{array}$ \\
\hline $\begin{array}{l}\text { Hamdan-Mansour } \\
\text { et al. 2010, } \\
\text { Jordan [20] }\end{array}$ & $\begin{array}{l}\text { Explore nurses' } \\
\text { knowledge and } \\
\text { management skills } \\
\text { of delirium in } \\
\text { critical care units }\end{array}$ & $\begin{array}{l}\text {-Significant correlation between knowledge } \\
\text { about delirium in patients in the } \\
\text { ICU had positive nursing practice }\end{array}$ & $\begin{array}{c}\text { Strengths } \\
\text { Selection of participants on } \\
\text { experience reduced selection bias } \\
\text { Weaknesses } \\
\text { The study was limited to } \\
\text { only critical care units }\end{array}$ \\
\hline $\begin{array}{l}\text { Fick et al. 2007, } \\
\text { Southeast, } \\
\text { USA [21] }\end{array}$ & $\begin{array}{l}\text { Investigate nurses’ } \\
\text { knowledge of Delirium } \\
\text { superimposed on de- } \\
\text { mentia (DSD) }\end{array}$ & $\begin{array}{l}\text {-The nurses had a high level of general } \\
\text { Psycho geriatric nursing knowledge as } \\
\text { measured by the MSHAKE } \\
-21 \% \text { identified the hypo-active form of DSD } \\
-41 \% \text { correctly identified hypoactive delirium }\end{array}$ & $\begin{array}{c}\text { Strengths } \\
\text { Validated standardised tools were used } \\
\text { Weaknesses } \\
\text { Participants number of } 29 \text { cannot } \\
\text { allow generalisation results } \\
\text { based on such a hospital study }\end{array}$ \\
\hline $\begin{array}{l}\text { Hosie et al. } \\
\text { 2014, } \\
\text { Australia [22] }\end{array}$ & $\begin{array}{l}\text { Investigate palliative } \\
\text { care nurses’ under- } \\
\text { standings, opinions and } \\
\text { practices in delirium } \\
\text { identification and as- } \\
\text { sessment }\end{array}$ & $\begin{array}{l}\text {-Systematic and structured delirium } \\
\text { screening and assessment processes and } \\
\text { application of the delirium diagnosis } \\
\text { criteria are largely missing } \\
\text {-Use of ambiguous terminology to } \\
\text { describe delirium symptoms } \\
\text { contributes to ineffective practice }\end{array}$ & $\begin{array}{c}\text { Strengths } \\
\text { Qualitative design enhanced } \\
\text { opinion understanding } \\
\text { Weaknesses } \\
\text { Study tools were validated } \\
\text { via pilot interviews. }\end{array}$ \\
\hline $\begin{array}{l}\text { Hare et al. 2008, } \\
\text { Western } \\
\text { Australia [23] }\end{array}$ & $\begin{array}{l}\text { Assess delirium } \\
\text { knowledge and risk } \\
\text { factors in nurses, } \\
\text { and find practical } \\
\text { and educational } \\
\text { implication of } \\
\text { the study results }\end{array}$ & $\begin{array}{l}\text {-The orthopaedic ward had the highest mean } \\
78 \% \text { for knowledge questions; the only ward } \\
\text { utilised specific intervention to improve deli- } \\
\text { rious/confused patients' management }\end{array}$ & $\begin{array}{c}\text { Strengths } \\
\text { Use of self-reported questionnaire } \\
\text { eased data collection } \\
\text { Weakness } \\
\text { Use of questionnaire subjected } \\
\text { it to recall bias on respondents }\end{array}$ \\
\hline
\end{tabular}




\begin{tabular}{|c|c|c|c|}
\hline \multicolumn{4}{|l|}{ Continued } \\
\hline $\begin{array}{c}\text { Meako et al. } \\
\text { 2011, } \\
\text { USA [24] }\end{array}$ & $\begin{array}{l}\text { Examine Orthopaedic } \\
\text { nurses' basic } \\
\text { knowledge about } \\
\text { delirium and test the } \\
\text { effectiveness of } \\
1 \text { hour teaching } \\
\text { session about it }\end{array}$ & $\begin{array}{l}\text {-Orthopaedic RNs have } \\
\text { a lack in understanding delirium } \\
\text {-The one hour educational session } \\
\text { is effective to raise RNs awareness }\end{array}$ & $\begin{array}{c}\text { Strengths } \\
\text { Quasi-experimental design allowed } \\
\text { accuracy in findings and validation. } \\
\text { Weaknesses } \\
\text { The study was liable to } \\
\text { participants drop out. }\end{array}$ \\
\hline $\begin{array}{c}\text { Steeg et al. } \\
\text { 2015, } \\
\text { Netherlands [25] }\end{array}$ & $\begin{array}{l}\text { Test the effectiveness } \\
\text { of an e-learning } \\
\text { course on nurses' } \\
\text { delirium knowledge } \\
\text { and explore their } \\
\text { knowledge } \\
\text { about delirium, }\end{array}$ & $\begin{array}{l}\text {-Test scores on the final knowledge test } \\
\text { were significantly higher than } \\
\text {-At baseline, nursing staff had the } \\
\text { most difficulty with questions related } \\
\text { to the definition of delirium: what are } \\
\text { its symptoms, course, consequences } \\
\text { and which patients are at risk }\end{array}$ & $\begin{array}{c}\text { Strengths } \\
\text { Randomisation minimised sample bias } \\
\text { Weaknesses } \\
\text { Pre and post design is open } \\
\text { to respondent attrition. }\end{array}$ \\
\hline $\begin{array}{l}\text { Rice et al. 2014, } \\
\text { south-eastern, } \\
\text { USA [26] }\end{array}$ & $\begin{array}{l}\text { Increase recognising } \\
\text { delirium clinical } \\
\text { reasoning for older } \\
\text { adults in nurses, and } \\
\text { provide clinical } \\
\text { reasoning processes } \\
\text { according to } \\
\text { participants to validate } \\
\text { these interventions }\end{array}$ & $\begin{array}{l}\text {-It was difficult for nurses to distinguish } \\
\text { acute versus chronic mental status changes, } \\
\text { especially in dementia patients } \\
\text {-The nurses' use of intuitive assessment of pa- } \\
\text { tients involved immediate knowledge that was } \\
\text { not mediated through rational } \\
\text { and analytical processes } \\
\text {-Nurses recognise that delirious patients } \\
\text { require different care and that being } \\
\text { confused altered their prognosis }\end{array}$ & $\begin{array}{l}\text { Strengths } \\
\text { The study had varied sample } \\
\text { from different wards } \\
\text { The study used validated tools } \\
\text { Weaknesses } \\
\text { The use of interviews exposed it } \\
\text { to respondent bias }\end{array}$ \\
\hline
\end{tabular}

rium was significantly correlated to nursing practices [20]. A study using a qualitative design with critical incident technique on a sample of 30 registered or enrolled nurses working in palliative care inpatient setting to investigate palliative care nurses' understandings, opinions and practice in delirium identification and assessment found that knowledge in systematic and structured delirium screening and assessment procedures and application of the delirium diagnosis criteria was largely missing [22]. Moreover, a study undertaken using qualitative semi-structured interviews on a sample of 40 nurses working for 6-months in different shifts to investigate the nurses' understanding of delirium assessment and management found that nurses understand cognitive or behavioral manifestations of delirium, but do not recognize the diagnostic criteria and these depended largely on the area of practice of the nurse [5]. Interestingly, the studies differed in terms of the methodology used but the results obtained in each of the studies agreed or supported the results obtained in the other studies.

For the four articles on knowledge development interventions, the study by Hare et al. (2008) and the study by Meako et al (2011) used survey questionnaire that were not valid because they had not been validated [23] [24]. The study Steeg et al. (2015) used validated 24 experimental questions as the assessment tool while the study by Rice et al. (2014) used validated Mini-Cog and CAM tools [25] [26]. A study undertaken using quantitative descriptive study on a sample of 338 nurses in one hospital to assess delirium knowledge and risk factors interestingly agree with the above findings by indicating that nurses have a low level of delirium knowledge, but indicates that this differs with the specific word where the nurse is attached with nurses in the orthopedic ward having the highest level of knowledge [23]. Interestingly, a study undertaken on a sample of 21 registered nurses from orthopedic unit using a quasi-experiment to examine the orthopedic nurses' basic knowledge about delirium disagreed with the findings in the above study by indicating that orthopedic registered nurses have a lack in understanding in delirium and therefore need educational sessions [24]. Interestingly, a study undertaken on a sample of 907 participants from internal medicine and surgical wards of 17 Dutch hospitals using a pre-test-andpost-test experimental study to test the effectiveness of an e-learning course on nurses' delirium knowledge established that nursing staffs have limited knowledge on delirium but this could be improved significantly through implementing an e-learning course [25]. Interestingly, the findings obtained from a study undertaken to investigate increase recognizing delirium clinical reasoning for older adults among nurses to validate the interventions using qualitative prospective mixed methods approach and semi-structured interviews on a sample of 31 nurses from five medical-surgical units agreed with the findings in the other studies by indicating that nurses find it difficult distinguish acute versus chronic mental status, the knowledge used by nurses to assess delirium patients was not rational and analytical and nurses where confused when assessing delirium patients [26]. Inte- 
restingly, the studies differed in terms of the methodology used but the results obtained in each of the studies agreed or supported the results obtained in the other studies.

\subsection{Nurses Knowledge of Dementia and the Relevant Knowledge Development Interventions (Table 2)}

As identified in the methodology, four articles on dementia were reviewed. Among the four articles, two were on knowledge of dementia and the remaining two articles were on knowledge development interventions. For the studies on knowledge of dementia, the study by Fessey (2007) undertaken in the UK used a validated questionnaire as the assessment tool while the study by Robinsone et al. (2014) used the 21 Dementia Knowledge Assessment Tool Version 2 (DKAT2), which is a highly valid and reliable dementia knowledge assessment tool [27] [28]. One of the studies was quantitative while the other one was both qualitative and quantitative. Interestingly, the research undertaken by Fessey (2007) using a mixed methods research on a sample of 49 registered nurses in adult care unit indicated that nurses have some knowledge and ability to deliver person-centered care, but there is a lack of consistency in the choices of approach [27]. Interestingly, another study undertaken using quantitative non-experimental study undertaken on a sample of 375 individuals that included nurses and health care workers and family members of dementia patients in Australia indicated that nurses and health care workers have significantly higher dementia knowledge when compared to family members and this was dependent on the years of experience of the nurses and healthcare workers [28]. Interestingly, the studies differed in terms of the methodology used but the results obtained in each of the studies agreed or supported the results obtained in the other studies.

For the two articles on knowledge development interventions, the study by Broughton et al. (2011) in Australia used a validated Positive Aspects of Care-giving Questionnaire and knowledge of support strategy test, which was not validated as the assessment tool while the study by Gandesha et al. (2012), undertaken in Eng-

Table 2. Nurses knowledge of dementia and the relevant knowledge development interventions.

\begin{tabular}{|c|c|c|c|}
\hline Authors \& Year & Aim & Findings & Strengths/Weaknesses \\
\hline $\begin{array}{c}\text { Broughton } \\
\text { et al. 2011, } \\
\text { Australia [12] }\end{array}$ & $\begin{array}{l}\text { Estimate the } \\
\text { effectiveness of } \\
\text { RECAPS and } \\
\text { MESSAGE training } \\
\text { on knowledge of } \\
\text { nursing home } \\
\text { staff in dementia } \\
\text { and evaluate } \\
\text { their opinions }\end{array}$ & $\begin{array}{l}\text {-Comparison of the training and control } \\
\text { groups revealed a significant increase in } \\
\text { knowledge for the training } \\
\text {-Only the qualified nurses showed higher le- } \\
\text { vels of caregiver satisfaction at 3-month } \\
\text { follow-up } \\
\text {-Staff rated the training positively } \\
\text { both for usefulness and applicability }\end{array}$ & $\begin{array}{l}\text { Strengths } \\
\text { Use of controlled pre and post trial } \\
\text { reduced bias, i.e. sample selection } \\
\text { Weaknesses } \\
\text { Use of support strategies, } \\
\text { knowledge that was not validated. }\end{array}$ \\
\hline $\begin{array}{c}\text { Fessey 2007, } \\
\text { UK [27] }\end{array}$ & $\begin{array}{c}\text { Explore nurses' } \\
\text { knowledge, } \\
\text { understanding, and } \\
\text { implications while caring } \\
\text { for patients with dementia } \\
\text { in general hospital wards }\end{array}$ & $\begin{array}{l}\text {-Nurses have some knowledge and } \\
\text { ability in delivering person-centered care } \\
\text {-Lack of consistency in the choices } \\
\text { of approach }\end{array}$ & $\begin{array}{c}\text { Strengths } \\
\text { Qualitative data collection enhanced } \\
\text { accurate reporting (Included comments) } \\
\text { Weaknesses } \\
\text { Findings can only be generalised } \\
\text { to such hospital settings. }\end{array}$ \\
\hline $\begin{array}{l}\text { Robinsone } \\
\text { et al. 2014, } \\
\text { (Vic, Tas, \& } \\
\text { WA), } \\
\text { Australia [28] }\end{array}$ & $\begin{array}{l}\text { Assess dementia } \\
\text { knowledge among } \\
\text { healthcare workers } \\
\text { and family carers }\end{array}$ & $\begin{array}{l}\text {-Significant high score of DKAT2 } \\
\text { for nurses and healthcare workers } \\
\text { than family members } \\
\text {-Significant correlation between high } \\
\text { score and year of experience for nurses } \\
\text { and healthcare workers }\end{array}$ & $\begin{array}{c}\text { Strengths } \\
\text { Used reliable and validated tools (DKAT2) } \\
\text { Weaknesses } \\
\text { Non-experimental design } \\
\text { reduces accuracy of results. }\end{array}$ \\
\hline $\begin{array}{l}\text { Gandesha et al. } \\
\qquad 2012 \text {, } \\
\text { England and } \\
\text { Wales [29] }\end{array}$ & $\begin{array}{l}\text { Observe and assess } \\
\text { the sufficiency of } \\
\text { dementia training } \\
\text { program among } \\
\text { healthcare workers, } \\
\text { and assess nurses' } \\
\text { adequacy of their } \\
\text { training among } \\
\text { different hospital } \\
\text { wards in particular }\end{array}$ & $\begin{array}{l}\text {-65\% Doctors sufficiency rate overall } \\
\text { mean for the } 13 \text { items, as higher than } \\
\text { qualified nurses at } 51 \% \text {, or HCAs at } 46 \% \\
\text {-Nurses rated the adequacy of their } \\
\text { training as particularly weak in the } \\
\text { field of mental health }\end{array}$ & $\begin{array}{c}\text { Strengths } \\
\text { Experimental study encouraged } \\
\text { more accurate results } \\
\text { Weaknesses } \\
\text { The study was open to } \\
\text { respondent attrition. }\end{array}$ \\
\hline
\end{tabular}


land and Wales used the validated regular training sessions questionnaire and both studies were quantitative [12] [29]. Interestingly, a study used an intervention study with post-test only and a sample of 2211 staffs of all general hospitals in England and Wales providing acute services to observe and assess the sufficiency of dementia training program among healthcare workers and how this differed across different hospital wards found that the programs had the greatest impact on doctors when compared to other health care workers, but the impacts were generally low among all the healthcare workers [29]. Another study undertaken using controlled pre- and post-test trials undertaken on a sample of 52 staffs from four nursing homes to estimate the effectiveness of RECAPS and MESSAGE training on knowledge of nursing home staff in dementia found that the training increase knowledge significantly and that the training was both useful and applicable [12]. Interestingly, the studies differed in terms of the methodology used but the results obtained in each of the studies agreed or supported the results obtained in the other studies.

\subsection{Nurses Knowledge of Depression and the Relevant Knowledge Development Interventions (Table 3)}

As identified in the methodology, five articles on depression were reviewed. Among the five articles, three were on both the knowledge of depression and the knowledge development interventions and the remaining two articles were on knowledge development interventions. Among the studies, a study by Butler \& Quayle (2007) undertaken in Ireland used already validated Late-Life Depression Quiz, Depression Attitude Questionnaire and

Table 3. Nurses knowledge of depression and the relevant knowledge development interventions.

\begin{tabular}{|c|c|c|c|}
\hline Authors \& Year & Aim & Findings & Strengths/Weaknesses \\
\hline $\begin{array}{c}\text { Daele } \\
\text { et al. 2014, } \\
\text { Belgium [13] }\end{array}$ & $\begin{array}{l}\text { Exploring the confidence and } \\
\text { attitude of home nurses in } \\
\text { professional competence } \\
\text { concerning depression, then } \\
\text { evaluate the capacity of } \\
\text { minimal intervention for } \\
\text { nurses to detect depression } \\
\text { in patients and caregiver }\end{array}$ & $\begin{array}{l}\text {-Nurses' attitude/confidence in professional } \\
\text { competences shows no significant changes, } \\
\text { but for the role attitude decline for } \\
\text { home nurses in the experimental group } \\
\text {-Significant differences in the intervention } \\
\text { group of identifying depressed patients } \\
\text { compared with controls }\end{array}$ & $\begin{array}{l}\text { Strengths } \\
\text { Quasi experimental design } \\
\text { allows more accurate results } \\
\text { Weaknesses } \\
\text { Follow up studies are open } \\
\text { to respondent attrition. }\end{array}$ \\
\hline $\begin{array}{l}\text { Butler \& } \\
\text { Quayle 2007, } \\
\text { Ireland } \\
\text { [30] }\end{array}$ & $\begin{array}{l}\text { Evaluate late-life depression } \\
\text { education effectiveness on } \\
\text { elevating nurses’ knowledge } \\
\text { and assess the educational impact } \\
\text { of nurses’ attitude toward } \\
\text { depressed elderly people }\end{array}$ & $\begin{array}{l}\text {-Significant differences in “correct and incorrect” } \\
\text { responses between pre- and post-training } \\
\text {-Attitudes towards depression were positive } \\
\text { following training which were significant } \\
\text {-Short training program on late-life } \\
\text { depression was effective }\end{array}$ & $\begin{array}{l}\text { Strengths } \\
\text { The study used validated } \\
\text { tools thus valid results } \\
\text { Weaknesses } \\
\text { Uncontrolled design results } \\
\text { to bias effects in study }\end{array}$ \\
\hline $\begin{array}{c}\text { Worrall-Carter } \\
\text { et al. 2012, } \\
\text { UK [31] }\end{array}$ & $\begin{array}{l}\text { Identify nurses’ knowledge } \\
\text { and practice regarding } \\
\text { depression screening and } \\
\text { referral for cardiac patients } \\
\text { following the implementation } \\
\text { of education workshops } \\
\text { and a validated screening } \\
\text { tool with referral actions }\end{array}$ & $\begin{array}{l}\text {-80\% reported a “good” understanding of depression, } \\
\text { post-program compared to } 30 \% \text { at baseline } \\
\text {-60\% reported routinely using the depression } \\
\text { screening and referral tool } \\
\text {-The interviews identified three main themes: } \\
\text { knowledge improvement; perceived } \\
\text { self-efficacy and new knowledge into practice }\end{array}$ & $\begin{array}{l}\text { Strengths } \\
\text { Use of validated tools } \\
\text { Weaknesses } \\
\text { Pre- and post-test design is } \\
\text { open to respondent attrition. }\end{array}$ \\
\hline $\begin{array}{c}\text { Sanders 2006, } \\
\text { USA [32] }\end{array}$ & $\begin{array}{l}\text { Explore the depression } \\
\text { screening practices of certified } \\
\text { nurse-midwives and certified } \\
\text { midwives and examine } \\
\text { its associated factors }\end{array}$ & $\begin{array}{l}\text {-Attitude, perceived ability, knowledge, and } \\
\text { education accounted for } 20 \% \text { of the variance } \\
\text { in depression screening conducted by certified } \\
\text { nurse-midwives and certified midwives }\end{array}$ & $\begin{array}{c}\text { Strengths } \\
\text { Participants distribution, } \\
\text { enhanced more varied results } \\
\text { with less sample bias effects } \\
\text { Weaknesses } \\
\text { Use individualized tool } \\
\text { reduced results quality }\end{array}$ \\
\hline $\begin{array}{c}\text { Choi et al. 2009, } \\
\text { USA [33] }\end{array}$ & $\begin{array}{l}\text { Examine nursing home staff } \\
\text { their opinions and experience } \\
\text { of residents' risk factors } \\
\text { of depression and explore } \\
\text { current intervention } \\
\text { programs and staff training }\end{array}$ & $\begin{array}{l}\text {-Participants indicate that the most common sign } \\
\text { of depression in residents is social withdrawal } \\
\text { as a result of grief, loss of control, independence, } \\
\text { anxiety, and changing of their past lifestyle } \\
-75 \% \text { of their residents' families were } \\
\text { not involved with their relative }\end{array}$ & $\begin{array}{c}\text { Strengths } \\
\text { Criteria of sample selection } \\
\text { reduced issues of bias } \\
\text { in sample selection } \\
\text { Weaknesses } \\
\text { Interviews used were } \\
\text { open to interviewer bias }\end{array}$ \\
\hline
\end{tabular}


Impact on Clinical Practice Questionnaire as the assessment tools while the study by Daele et al. (2014) undertaken in Belgium used Depression Attitude Questionnaire and an already validated Morris Confidence Scale as the assessment tool [13] [30]. The study undertaken by Worrall-Carter et al. (2012) in the UK used an already validated and reliable Cardiac Depression Scale as the assessment tool and a study by Sanders (2006) undertaken in the USA used un-validated 33-item survey questionnaire developed by the author as the assessment tool, while a study by Choi et al. (2009) undertaken in the USA used semi-structured interviews as the assessment tools [31]-[33]. Interestingly, four of the studies were quantitative while only one study was qualitative.

A study undertaken qualitatively on a sample of 25 participants that included administrators, nurses and social workers from 8 nursing homes in central Texas to examine nursing home staffs' opinions and experience of residents' risk factors of depression and explore current intervention programs and staff training indicated that the staffs lack adequate knowledge on residents' risk factors of depression but this could be improved significantly through intervention programs and staff training [33]. A study undertaken quantitatively on a sample of 378 attending the American College of Nurse-Midwives annual meeting to explore the depression screening practices of certified nurse-midwives and certified midwives and examine its associated factors found that attitude, perceived ability, knowledge and education accounted for $20 \%$ of the variance in depression screening conducted by the nurse-midwives and certified midwives [32]. Interestingly, a study undertaken using a quasi-experiment on a sample of 92 nurses, 63 in the intervention group and 29 in the control group to explore the confidence and attitude of home nurses in professional competence concerning depression and evaluate the capacity of minimal intervention for nurses to detect depression in patients and caregiver found that the intervention group did not differ significantly from the control group in terms of nurses' attitude/confidence in professional competences but the role attitude was significantly lower in the experimental group [13]. Moreover, the same study found that participants in the intervention group differed significantly from those in the control group in terms of identifying depressed patients [13]. Intriguingly, the study undertaken using pre- and post-test design on a sample of 84 nurses to identify nurses knowledge and practice regarding depression screening and referral for cardiac patients following the implementation of education workshops and a validated screening tool with referral actions found that implemented education workshops and validated screening tool with referrals improved understanding of depression by about $50 \%$ and the interventions are popularly used resulting to knowledge improvement and perceived self-efficacy [31]. The study undertaken by Butler \& Quayle (2007) using uncontrolled pre- and post-test design on a sample of 67 nurses to evaluate to evaluate late-life depression education knowledge and assess the educational impact of nurses’ attitude towards depressed elderly people found that training was significant in the improvement of nurses’ depression knowledge and attitude towards depression [30]. Interestingly, the studies differed in terms of the methodology used but the results obtained in each of the studies agreed or supported the results obtained in the other studies.

\section{Discussion}

Managing patients with 3Ds is considered a professional challenge among nurses. Studies have shown low levels of relevant knowledge among nurses working with such patients, and some nurses faced difficulty to describe symptoms of delirium and dementia [17] [34]. This could be attributed to lack of adequate education, where to appropriately diagnose and treat 3Ds, nurses would most likely rely on their relevant knowledge. Apart from that, there are many methods, included in the nursing curricula, for assessing such mental disorders, and for nurses to screen patients with the 3Ds. For best practices, psychogeriatric nurses should learn skills and knowledge of solving the associated problems, and to know how to successfully face the challenges, and critically analyze the professional practice situations [35].

It is evident that nurses are the bases of the healthcare system that provides care and support to the patients. Therefore, it is important for any nurse to know about every medical illness's symptoms and treatment approaches within her/his field of specialty. Generally, patients with mental disorders are difficult to take care of because of the challenges associated with their illnesses such as distinguishing between dementia and delirium. Geriatric patients, with mental health challenges, usually have difficulty in managing their daily life activities, in addition to the fact that their behavior makes them aloof from others. Under such circumstances, they feel loneliness because of their age and mental disorders [3]. Hence, the only thing that may help them get back to normal living is the support they receive from their families, and understanding and professional care from the surrounding nursing and other hospital staff. Therefore, nurses should learn and gain more understanding about 3Ds, 
and develop their psychogeriatric nursing practices. Moreover, knowledge of these conditions has been found to be influenced by the level of professional experience [4] [12].

It is evident that negative attitudes of nurses towards 3Ds, are a challenge for most of them, and training of nurses caused that their attitudes became more positive towards patients with 3Ds [3] [30] [32]. There is an urgent need to provide quality care to cater for the rising number of 3Ds' cases, especially among the elderly [35]. This is because of their vulnerability and high chances of inadequate care that they are likely to receive from nurses as compared with other healthcare professionals. In this regard, Gandesha et al. (2012) confirmed that provision of quality care was found to be significantly correlated with improved knowledge and more training among healthcare workers, and that training among nurses has been postulated to be effective, especially in increasing nurses' awareness of 3Ds' management techniques [29]. This was a confirmation of another study's finding that one hour training session was able to create awareness of 3Ds among nurses [30]. This indicates that training would be effective as a capacity building strategy among nurses. Furthermore, training as an intervention to improve knowledge of 3Ds, was recognized by nurses following an interview on the benefits of such training, and their higher scores after the training [25]. Accordingly, nurses can greatly benefit from a solid foundation of knowledge about the identification, classification and management of the three overlapping health conditions, i.e. the 3Ds.

To improve patients' health outcome, there is a need to improve nurses' knowledge of the 3Ds, through training on direct communication, structured assessments, observations, pharmacological approaches, assistance with daily life activities, as well as non-pharmacological approaches, such as physiotherapy, aromatherapy, music therapy and cognitive behavioral therapy [4] [15]. The nurses also need capacity building, so they can play a vital role in offering psychosocial interventions to help relieve their clients psychological distress such as feelings of grief, depression and loneliness [16]. Moreover, nurses need to be updated with the best available clinical evidence so they can improve their professional practices for the elderly.

Despite all the challenges facing geriatric people and their caregivers, the 3D's are still commonly considered part of the normal aging process, while it should not. For instance, dementia is not an inevitable process even though it is commonly believed that memory loss and declining functional abilities are normal occurrences associated with aging [20] [21]. In this regard, it is important that psychogeriatric nurses develop a clear understanding of psychiatric symptomatology to be able to differentiate normal aged-related changes from psychological disorders. Furthermore, improved nursing knowledge and understanding of psychogeriatric disorders have been suggested as predictors of success among 3Ds patients, and improved quality of healthcare [8] [18] [23]. Therefore, there is a need to improve understanding among psychogeriatric nurses by increasing their knowledge of the symptoms, and be able to identify access to, and use of, appropriate screening tools as part of developing their professional practice.

\section{Conclusion}

The 3Ds comprise a challenge not only for the elderly, but for the whole population as well. Nurses face a challenge to differentiate between the 3Ds, especially their diagnosis and Treatment. This is because their considerable overlap and the simultaneous existence of the three conditions in the individual patients. Older patients are more vulnerable than other age groups; hence, nurses need more specific knowledge of 3Ds management strategies within the older age group. The primary care providers can undoubtedly benefit from a solid foundation of knowledge in the identification, classification, and treatment of these common health problems among the elderly. Therefore, 3Ds specific education courses, or workshops, need to be an integral part of any professional development programs for psychogeriatric nurses.

\section{Acknowledgements}

Many thanks for first author's husband Amr Alalawi and parents for their support during accomplishing this study.

\section{References}

[1] WHO (2013) Mental Health and Older Adults. World Health Organisation Factsheet, WHO Press.

[2] Seitz, D., Purandare, N. and Conn, D. (2010) Prevalence of Psychiatric Disorders among Older Adults in Long-Term 
Care Homes: A Systematic Review. International Psychogeriatrics Journal, 22, 1025-1039. http://dx.doi.org/10.1017/S1041610210000608

[3] Olivera, J., Benabarre, S., Lorente, T., Rodriguez, M., Barros, A., Quintana, C., Pelegrina, V. and Aldea, C. (2011) Detecting Psychogeriatric Problems in Primary Care: Factors Related to Psychiatric Symptoms in Older Community Patients. Mental Health in Family Medicine, 8, 11-19.

[4] Reuben, D., Herr, K., Pacala, J., Pollock, B., Potter, J. and Semla, T. (2013) Geriatrics at Your Fingertips. 15th Edition, American Geriatrics Society Publications/Fry Communications, Mechanicsburg.

[5] Agar, M., Draper, B., Phillips, P., Phillips, J., Collier, A., Harlum, J. and Currow, D. (2011) Making Decisions about Delirium: A Qualitative Comparison of Decision Making between Nurses Working in Palliative Care, Aged Care, Aged Care Psychiatry, and Oncology. Palliative Medicine, 26, 887-896. http://dx.doi.org/10.1177/0269216311419884

[6] Downing, L., Caprio, T. and Lyness, J. (2013) Geriatric Psychiatry Review: Differential Diagnosis and Treatment of the 3 D's-Delirium, Dementia, and Depression. Current Psychiatry Reports, 15, 1-10. http://dx.doi.org/10.1007/s11920-013-0365-4

[7] Zarit, S. and Zarit, J. (2012) Mental Disorders in Older Adults: Fundamentals of Assessment and Treatment. 2nd Edition, Guilford Press, New York.

[8] Savva, G., Wharton, S., Ince, P., Forster, G., Matthews, F. and Brayne, C. (2009) Age, Neuropathology, and Dementia. New England Journal of Medicine, 360, 2302-2309. http://dx.doi.org/10.1056/NEJMoa0806142

[9] Sampson, E., Candy, B. and Jones, L. (2009) Enteral Tube Feeding for Older People with Advanced Dementia. 2nd Edition, John Wiley \& Sons Ltd., Chichester. http://dx.doi.org/10.1002/14651858.cd007209.pub2

[10] Cohen, C., Hyland, K. and Kimhy, D. (2003) The Utility of Mandatory Depression Screening of Dementia Patients in Nursing Homes. American Journal of Psychiatry, 160, 2012-2017. http://dx.doi.org/10.1176/appi.ajp.160.11.2012

[11] Collet, J., Vugt, M., Verhey, F. and Schols, J. (2010) Efficacy of Integrated Interventions Combining Psychiatric Care and Nursing Home Care for Nursing Home Residents: A Review of the Literature. International Journal of Geriatric Psychiatry, 25, 3-13.

[12] Broughton, M., Smith, E., Baker, R., Angwin, A., Pachana, N., Copland, D., Humphreys, M., Gallois, C., Byrne, G. and Chenery, H. (2011) Evaluation of a Caregiver Education Program to Support Memory and Communication in Dementia: A Controlled Pretest-Posttest Study with Nursing Home Staff. International Journal of Nursing Studies, 48, 1436-1444. http://dx.doi.org/10.1016/j.ijnurstu.2011.05.007

[13] Daele, T., Vansteenwegwn, D., Hermans, D., Bergh, O. and Audenhove, C. (2014) Home Nurses and Patient Depression: Attitudes, Competences and the Effects of a Minimal Intervention. Journal of Advanced Nursing, 71, 126-135. http://dx.doi.org/10.1111/jan.12476

[14] Donahue, M., Kazer, M., Smith, L. and Fitzpatrick, J. (2011) Effect of a Geriatric Nurse Education Program on the Knowledge, Attitudes, and Certification of Hospital Nurses. The Journal of Continuing Education in Nursing, 42, 360-364. http://dx.doi.org/10.3928/00220124-20110415-01

[15] Tolson, D., Rolland, Y., Andrieu, S., Aquino, J.P., Beard, J., Benetos, A., Berrut, G., Coll-Planas, L., Dong, B., Forette, F., Franco, A., Franzoni, S., Salvà, A., Swagerty, D., Trabucchi, M., Vellas, B., Volicer, L. and Morley, J. (2011) International Association of Gerontology and Geriatrics: A Global Agenda for Clinical Research and Quality of Care in Nursing Homes. Journal of the American Medical Directors Association, 12, 184-189. http://dx.doi.org/10.1016/j.jamda.2010.12.013

[16] Morley, J. (2010) Depression in Nursing Home Residents. Journal of the American Medical Directors Association, 11, 301-333. http://dx.doi.org/10.1016/j.jamda.2010.03.012

[17] Baker, N., Taggart, H., Nivens, A. and Tillman, P. (2015) Delirium: Why Nurses Are Confused? MEDSURG Nursing: Research for Practice, 24, 15-22.

[18] Christensen, M. (2014) An Exploratory Study of Staff Nurses’ Knowledge of Delirium in the Medical ICU: Asian Perspective. Intensive and Critical Care Nursing, 30, 54-60. http://dx.doi.org/10.1016/j.iccn.2013.08.004

[19] Fick, D., Hodo, D., Lawrence, F. and Inouye, S. (2007) Recognizing Delirium Superimposed on Dementia: Assessing Nurses’ Knowledge Using Case Vignettes. Journal of Gerontological Nursing, 33, 40-47.

[20] Flagg, B., Cox, L., Mcdowell, S., Mwose, J. and Buelow, J. (2010) Nursing Identification of Delirium. Clinical Nurse Specialist, 24, 260-266. http://dx.doi.org/10.1097/NUR.0b013e3181ee5f95

[21] Hamdan-Mansour, A., Farhan, N., Othman, E. and Yacoub, M. (2010) Knowledge and Nursing Practice of Critical Care Nurses Caring for Patients with Delirium in Intensive Care Units in Jordan. The Journal of Continuing Education in Nursing, 41, 571-676. http://dx.doi.org/10.3928/00220124-20100802-01

[22] Hosie, A., Agar, M., Lobb, E., Davidson, P. and Phillips, J. (2014) Palliative Care Nurses' Recognition and Assessment of Patients with Delirium Symptoms: A Qualitative Study Using Critical Incident Technique. International 
Journal of Nursing Studies, 51, 1353-1365. http://dx.doi.org/10.1016/j.ijnurstu.2014.02.005

[23] Hare, M., Wynaden, D., McGowan, S., Landsborough, I. and Speed, G. (2008) A Questionnaire to Determine Nurses’ Knowledge of Delirium and Its Risk Factors. Contemporary Nurse, 29, 23-31. http://dx.doi.org/10.5172/conu.673.29.1.23

[24] Meako, M., Thompson, H. and Cochrane, B. (2011) Orthopaedic Nurses’ Knowledge of Delirium in Older Hospitalized Patients. Orthopaedic Nursing, 30, 241-248. http://dx.doi.org/10.1097/NOR.0b013e3182247c2b

[25] Steeg, L., LJkema, R., Wagner, C. and Langelaan, M. (2015) The Effect of an E-Learning Course on Nursing Staff's Knowledge of Delirium: A Before-and-After Study. BMC Medical Education Journal, 15, 12. http://dx.doi.org/10.1186/s12909-015-0289-2

[26] Rice, K., Bennett, M., Clesi, T. and Linville, L. (2014) Mixed-Methods Approach to Understanding Nurses' Clinical Reasoning in Recognizing Delirium in Hospitalized Older Adults. The Journal of Continuing Education in Nursing, 45 , 136-148. http://dx.doi.org/10.3928/00220124-20140219-02

[27] Fessey, V. (2007) Patients Who Present with Dementia: Exploring the Knowledge of Hospital Nurses. Nursing Older People, 19, 29-33. http://dx.doi.org/10.7748/nop2007.12.19.10.29.c8246

[28] Robinsone, A., Eccleston, C., Annear M., Elliott, K.E., Andrews, S., Stirling, C., Ashby, M., Donohue, C., Banks, S., Toye, C. and Mclnerney, F. (2014) Who Knows, Who Cares? Dementia Knowledge among Nurses, Care Workers, and Family Members of People Living with Dementia. Journal of Palliative Care, 30, 158-165.

[29] Gandesha A., Souza, R., Chaplin, R. and Hood, C. (2012) Adequacy of Training in Dementia Care for Acute Hospital Staff. Nursing Older People, 24, 26-31. http://dx.doi.org/10.7748/nop2012.05.24.4.26.c9070

[30] Butler, M.P. and Quayle, E. (2007) Training Primary Care Nurses in Late-Life Depression: Knowledge, Attitude and Practice Change. International Journal of Older People Nursing, 2, 25-35. http://dx.doi.org/10.1111/j.1748-3743.2007.00054.x

[31] Worrall-Carter, L., Ski, C., Thompson, D., Davidson, P., Cameron, J., Castle, D. and Page, K. (2012) Recognition and Referral of Depression in Patients with Heart Disease. European Journal of Cardiovascular Nursing, 11, 231-238.

[32] Sanders, L. (2006) Attitudes, Perceived Ability, and Knowledge about Depression Screening: A Survey of Certified Nurse-Midwives/Certified Midwives. Journal of Midwifery and Women's Health, 51, 340-346. http://dx.doi.org/10.1016/j.jmwh.2006.02.011

[33] Choi, N., Wyllie, R. and Ransom, S. (2009) Risk Factors and Intervention Programs for Depression in Nursing Home Residents: Nursing Home Staff Interview Findings. Journal of Gerontological Social Work, 52, 668-685. http://dx.doi.org/10.1080/01634370802609155

[34] Smith, J. and Seirafi, J. (2011) Delirium and Dementia. In: Rakel, R., Eds., Textbook of Family Medicine, 8th Edition, Saunders Elsevier Publication, Philadelphia.

[35] Ames, D., Chiu, E., Lindesay, J. and Shulman, K.I. (2010) Guide to the Psychiatry of Old Age. Cambridge University Press, New York. http://dx.doi.org/10.1017/CBO9780511776984 